\title{
Theoretical Perspective of Job Demands Correlates among Nurses: Systematic Literature Review
}

\author{
Manar Ali Bani-Hani' ${ }^{1}$, Ayman M. Hamdan-Mansour², Huda Mohammad Atiyeh'1, Eman Tariq Alslman1 \\ ${ }^{1}$ School of Nursing, The University of Jordan, Amman, Jordan \\ ${ }^{2}$ Department of Community Health Nursing, School of Nursing, The University of Jordan, Amman, Jordan \\ Email: manaryousef2013@gmail.com, a.mansour@ju.edu.jo, aymanjabay@gmail.com, huda_atiyeh@yahoo.com, \\ eman.yassen@hotmail.com
}

How to cite this paper: Bani-Hani, M.A., Hamdan-Mansour, A.M., Atiyeh, H.M. and Alslman, E.T. (2016) Theoretical Perspective of Job Demands Correlates among Nurses: Systematic Literature Review. Health, 8, 17441758.

http://dx.doi.org/10.4236/health.2016.815168

Received: November 1, 2016

Accepted: December 6, 2016

Published: December 9, 2016

Copyright $\odot 2016$ by authors and Scientific Research Publishing Inc. This work is licensed under the Creative Commons Attribution International License (CC BY 4.0).

http://creativecommons.org/licenses/by/4.0/ (c) (i) Open Access

\begin{abstract}
Introduction: Nursing is highly demanding and stressful profession. Negative consequences of job demands were widely discussed throughout the literature like; poor quality of care, poor health, burnout, greater intent to leave and lower level of job satisfaction. Job dissatisfaction among nurses also has been discussed exhaustively in the literature in regards to its negative outcomes represented by burnout, absenteeism, turnover, greater intent to leave and finally leaving nursing profession. Purpose: The purpose of this study was to examine literature discussing job demands in nursing profession and its associated factors among nurses, and to provide direction as to where research needs to continue to explore and develop evidence in this area. Results: Results showed that job demands are the most influential stressor in nursing profession that associated strongly with many negative consequences on the profession in general and on the nurses on particular. Conclusion: The results supported that job demand is unavoidable stressor that leads to many negative consequences and connects directly to job dissatisfaction. Therefore, there is a need to search for alleviating factors that decrease nursing stressor, its consequences and buffer the correlation between job demand and job satisfaction.
\end{abstract}

\section{Keywords}

Nursing, Job Demand, Job Satisfaction, Job Stress, Organizational Work Environment

\section{Introduction}

The global concerns are increasing toward factors that interfere with nursing profession 
and quality of nursing care provided. Shortage of nurses, increasing job demands, increasing patients' health needs and demands, and the industrial health issues are among the main concerns that nurses are challenged with nowadays and for the next few decades. This has evoked nurse managers and administrators to re-emphasize the organizational and personal health related factors that can be managed and lessen nurses burnout and turnover. Amongst are the work stress, job demands and nurses' satisfaction. The quality of care managers did recognize that such factors if remained unaddressed would jeopardize the quality health care services and may interfere with the ultimate goals for health institutions that focus on cost-effective health care. Nurse's managers are assumed to take an effective role toward such efforts and address these issues and manage at short- and long-term perspective.

Work stress in nursing profession is among the universal problems that challenge nurses and nursing performance. Nursing profession is a stressful and highly demanding profession; where most of the nurses reported high to very high job stress or strain [1] [2] [3] [4] [5]. An International Labor Organization [6] study indicated that nursing profession is ranked 12 among the top 20 stressful occupations. Consistently, Moustaka and Constantinidis [4], Cho et al. [7] reported that nurses were under greatest pressure among all other health care personnel. Moreover, negative outcomes of job demands among nurses are economically exhausting to health organizations, and further contribute to illness, decrease overall quality of care, staff turnover, absenteeism and job dissatisfaction.

Nursing care requires that nurses provide a holistic perspective of care that includes emotional, physical, quantitative and work shift demands [7] [8]. Those demands have been clearly established in the literature as job stressors. However, emotional demands, dealing with suffering and interpersonal conflict may arouse and exacerbate job demands among nurses [8] [9] [10] [11]. Nursing job demands vary in types and nature depending on the area of practice and severity of patient condition. Among the job demands types is the physical one where nurses might be exposed to long working hours, poor working condition, and mandated systems of overtime working hours [7]. Furthermore, limited resources and working environment with higher nurse-patient ratio are other types of physical demands on nurses [11] [12] [13]. Quantitative demand or workload refers to the amount of work that individuals perceive which is expected of them within a little time and operationalized in terms of (high) work pace [14]. While nurses are required to perform their job and provide a quality of nursing care, nurses are, on the other hand, struggling to manage stress produced by demands of the job [15]. Previous studies showed that nurses who reported high level of job demands had poor health and job outcomes and low level of job satisfaction [7] [16] [17]. Consistently, other studies revealed that higher quantitative and emotional demands are associated with poor self-rated health, higher sleeping troubles, work-family conflict resulting in multiple role conflicts and strains, burnout, greater intent to leave and lower job satisfaction [7] [18] [19]. So, it is evident that numerous studies supported the idea that high level of nurses' job demands is associated strongly and significantly with low level 
of nurses' job satisfaction (e.g., [7] [16] [17]). Thus, the link is well established between job demands and job dissatisfaction in the literatures.

Job dissatisfaction among nurses has been reported strongly to associate with negative consequences such as intent to leave [20] [21] [22], poor quality of care, high turnover [23], and high costs of nurses turnover [24]. In addition, low level of job satisfaction leads to higher absenteeism causing further economic burden on the institution [25] [26]. Furthermore, nurses' job dissatisfaction may be connected to leaving the profession [27]. Thus, the literature has provided evidence that job demands and job satisfaction are connected and they might also contribute to further negative consequences regarding the quality of care and the institutional outcomes [23] [28].

\section{Methods}

\subsection{Data Source}

An exhaustive review of literature was conducted using various databases including; Science Direct, Medline, Pubmed, EBSCOhost, Google Scholar, CINAHL Plus, ProQuest databases using the following key words; Nursing, job demand, job satisfaction, quality of nursing care, job stress, organizational work environment, Jordan. Filtration was done to all articles to remove the irrelevant, non-nursing, and duplicated articles. The inclusion criteria were: publications in English language, relevance to the study question, any study design; qualitative, quantitative, mixed methods, systematic reviews. Articles reference lists were manually searched, traced and examined for any relevance and significance in the literature that were not identified through the electronic databases. The exclusion criteria included studies that were not relevant to the study purpose, non-nursing studies, and studies published in languages other than English (see Table 1).

\subsection{Definitions and Perspectives of Job Demands}

The concept of Job demand has been addressed in different perspectives in the literature. While some referred to job demands as the extent to which working environment contains stimuli that need extra effort to achieve work goals leading to negative consequences [7] [16] [17] [29] [30]. Others maintained that job demand is the aspects of job that require continued effort leading to significant costs [31].

Table 1. Summary of literature search.

\begin{tabular}{|c|c|c|}
\hline Databases Searched & Inclusion Criteria & Exclusion Criteria \\
\hline $\begin{array}{l}\text { - } \text { ScienceDirect } \\
\text { - } \text { Medline } \\
\text { - } \text { Pubmed } \\
\text { - } \text { EBSCOhost } \\
\text { - } \text { Google Scholar } \\
\text { - } \text { CINAHL Plus } \\
\text { - }\end{array}$ & $\begin{array}{l}\text { - Publications in English language } \\
\text { - Relevance to the study question } \\
\text { - Any study design }\end{array}$ & $\begin{array}{l}\text { - Studies that were not relevant to the } \\
\text { study purpose } \\
\text { - } \quad \text { Non-nursing studies } \\
\text { - Studies published in languages other } \\
\text { than English }\end{array}$ \\
\hline
\end{tabular}


Al-Homyan et al. [14] considered job demands as physical, psychological (emotional), quantitative (workload), and work shift demands. While others [32] [33] believe that job demand includes physical (work overload), psycho-emotional (continuous contact with suffering and death), social (interacting with co-workers) or organizational (job complexity) aspects of the job that require continuous efforts and are associated with certain physiological and psychological costs. Cho et al. [7] considered job demand as quantitative demands, emotional demands and work pace. Whereas, Demerouti et al. [34] measured job demand as workload, physical demands and patient demands.

Job demands is a concept that contains different aspects where researchers reported various forms that are considered as parts of job demands, among nurses in particular. Kar and Suar [35] asserted that Job demands reflects role conflict, role ambiguity, workload, work-home conflict, shift work attitude, patient care demand, perception of organizational politics, job complexity, and physical environment. See the summary in Table 2.

\subsection{Job Demand as a Source of Stress in Nursing Profession}

Number of studies has identified nursing as a highly stressful and demanding profession. Studies reported that most nurses had high to very high job stress or strain [1] [2] [3] [4]. The consequences of stress have been recognized to jeopardize quality of nursing care and organizational outcomes. Moustaka \& Constantinidis [4] conducted a systematic review of 42 research studies to examine sources and consequences of occupational stress on nurses' adequacy, productivity and efficiency. They found that occupational stress is mostly affected by working environment such as work overload, role ambiguity, role conflict and lack of power. This links occupational stress to decrease efficiency, capacity to achieve, and lack of concern for the organization and colleagues' interaction and achievement.

Table 2. Summary of job demands definitions and perspectives.

\begin{tabular}{ll}
\hline \multicolumn{1}{c}{ Job demand definition or perspective } & \multicolumn{1}{c}{ Authors and years } \\
\hline $\begin{array}{l}\text { The extent to which working environment contains stimuli that need extra effort to achieve work } \\
\text { goals leading to negative consequences }\end{array}$ & $\begin{array}{l}\text { Peeters et al. (2005); Cho et al. (2014); Hayes } \\
\text { et al. (2012); Lu, et al. (2012); McVicar (2003) }\end{array}$ \\
The aspects of job that require continued effort leading to significant costs & Beutell (2010) \\
Psychological (emotional), quantitative (workload), and work shift demands & Al-Homyan et al. (2013) \\
$\begin{array}{l}\text { Physical (work overload), psycho-emotional (continuous contact with suffering and death), social } \\
\text { (interacting with co-workers) or organizational (job complexity) aspects of the job that require } \\
\text { continuous efforts and are associated with certain physiological and psychological costs }\end{array}$ & Demerouti et al. (2001); Lee \& Akhtar (2011) \\
$\begin{array}{l}\text { Quantitative demands, emotional demands and work pace } \\
\text { Workload, physical demands and patient demands }\end{array}$ & Cho et al. (2014) \\
$\begin{array}{l}\text { Role conflict, role ambiguity, workload, work-home conflict, shift work attitude, patient care demand, } \\
\text { perception of organizational politics, job complexity, and physical environment }\end{array}$ & Kar and Suar (2014) \\
\hline
\end{tabular}


The fact that occupational stress is interrelated and complex concept do apply to nursing profession. For example, Moustaka \& Constantinidis [4] maintained that occupational stress arises from physical, psychological, and social aspects of the work environment and that high level of stress results in staff burnout and turnover and adversely affect quality of nursing care. Occupational stress, interchangeably referred to as work stress, among nurses found to associate with negative outcomes in the workplace including lower job satisfaction [5] [36], high rate of turnover, burnout, lower productivity and absenteeism [4] [37]. Work stress has also found to disrupt nurses' physical, psychological, and social wellbeing [38] [39].

Researchers have identified three categories of factors that seem to be associated with stress among nurses: demographic factors such as nursing experience, grade and age; buffering factors, including coping strategies; and organizational factors, including occupational stressors [40]. In their study, Greenlass, Burke and Fiksenbaum [41] demonstrated that workload was positively correlated with emotional exhaustion, with negative effects on professional efficacy. Ewers et al. [42] evaluated the effect of psychosocial intervention training (PSI) on stress levels among nurses and found positive effect on their attitudes, knowledge and clinical burnout levels. Furthermore, the stress, appraisal and coping model describes particular psychological processes that come into play between exposure to physiological activation and conditions that are potentially stressful [43]. The central tenet of this model is that a likely stressful event will stimulate a primary process of appraisal in which a person assesses the threat degree in relation to their wellbeing [44]. This raised the significant positive contribution of healthy environment, appropriate leadership and management styles on level of stress among nurse.

\subsection{Job Demand as Significant Stressor}

While literature identified nursing profession as a stressful profession, the fact that stress is not what affect nurses as much as being in highly demanding profession. It has been reported that nursing profession requires nurses to perform multiple functions and tasks [30] [45] [46]. These tasks include long working hours, night shifts, pressured working conditions, shortage of staff, and dealing with death and dying patients [47] [48] [49]. These occupational stressors had been translated and referred to as job demands (e.g., [14] [45] [46]). Santos et al. [50] sustained that job characteristics such as job demands may include physical, psychological or social. Moreover, high levels of job demands among nurses has been considered a significant source of stress in nursing profession, and the work stress will result in more negative perception of work environment resulting in higher levels of job demands represented by, work overload, dealing with dying and death as well as emotional exhaustion [2]. There is almost an agreement in the literature that job demands are the most significant stressors in nursing profession [30] [45] [46]. This makes job demands in nursing as one main challenge to nursing quality of care and stability of organizational structure and processes.

In Jordan, job stress has never been addressed solely; it is rather in relationship to 
other significant personal and organizational factors. A study conducted by AlMa'aitah et al. [51], although conducted while ago but among the fewest, involved a sample of 479 nurses (68\% female, $32 \%$ male) employed in public and military hospitals revealed negative association between job stress or burnout and intention to stay at work. Consistently, Abu Alrub [52] revealed similar results in the public sector, where four hospitals and 206 staff nurses were recruited. That is, nurses who experienced a lower level of job stress reported a higher level of intention to stay at work than nurses who experienced a higher level of job stress.

Lazarus \& Folkman [53] in their stress and coping model stated that job demands perceived as a stressor when it exceeds ability to manage and cope. Supported by Doherty \& Tyson [54] in their book, stated that stress is a state experienced as a result of exposure to high level of job demands, which may affect the employees' health and be an illness or an injury, or cause changes in their behavior and even in their lifestyle.

Job demands in nursing is considered one of the job component stressors including time pressure and deadlines, handling clients and clients' families, coping with dying and death (emotional demands), heavy workload as well [2]. Supported by Al-Homyan et al. [14] who considered job demands in nursing profession as job stressor represented by quantitative demands, physical demands, emotional demands, and shift work. Thus, studies indicated that occupational stress in nursing is associated with many factors, and considered job demands as the most important stressor in the nursing profession [30] [45] [46].

\subsection{Correlates of Job Demands among Nurses}

While job demand is a factor that concerns all workers at their various occupational and professional levels, the literature has significantly addressed job demand among nurses and health care professionals. This significant attribution is much related to the substantial aspects and obvious consequences of demands on nursing performance and quality of care. Moreover, job demand has been addressed as an inevitable factor among healthcare professionals at their different levels including nurses [35]. Studies showed that nurses are exposed to work pressure, and work an unfavorable physical environment at workplace which makes nursing profession more harrowing [33] [55]. Nurses often find it difficult to continue in such work settings and fail to manage, and thus, suffer high levels of burnout [33] [55] [56]. This may contribute to nurses' negative perception of their work environment, and negatively influence their intention to stay at their organizations [35].

In a cross sectional study conducted by Cho et al. [7] in a tertiary university hospital in Korea, including 746 staff nurses working on 36 general, oncology, or intensive care units. Researchers examined the relationships between job demands and nurses' health and job outcomes. They measured job demands as quantitative demands, work pace, and emotional demands to find that nurses reported high mean scores of job demands and poor health and job outcomes, compared with other occupations. Moreover, they emphasized on the length of stay in the unit and stated that nurses working on a short 
or medium length of stay (LOS) units perceived higher quantitative, emotional demands, and a higher work pace. That was correlated with poor self-rated health, higher sleeping troubles, work-family conflict, stress and burnout, greater intent to leave and lower job satisfaction. In addition, a greater work pace was significantly related to greater work-family conflict as well. Finally, the researchers suggested that nurse managers should to avoid high job demand to prevent worse nurses' health and job outcomes by recruitment of additional nurses to meet the increasing job demands.

These findings were consistent with results from two previous systematic reviews studies conducted in 2012, in which excessive workloads and work demands were associated with negative consequences represented with high level of nurses' job dissatisfaction, intent to leave, and turnover [16] [17]. In addition, high job demand represented with work overload was also related to increased sleep impairment, stress, fatigue, and work-family conflict [19] [18].

Demerouti et al. [34] indicated other nursing high job demands negative consequences; burnout (exhaustion and depersonalization), and presenteeism. (The opposite of absenteeism, it is the phenomenon of employees stay at work when they should be at home or off sick). This longitudinal study (three time measurement points with 1.5 years) examined the relationships between job demands, burnout, and presenteeism that found Job demands strongly associated with presenteeism, which over time cause depersonalization as an outcome. A reciprocal relationship was founded between exhaustion and presenteeism, justified by when nurses become exhausted, they utilize compensation strategies, which eventually increases their exhaustion. Demerouti also supported the idea that job demands may have a strong effect on exhaustion in two studies [57] [58]. Moreover, Al-Homyan et al. [14] added the impacts of high job demands on decreasing nurses' performance working in public hospitals in the Saudi Arabia. Consistently, Mohamed \& Mohamed [59] found that job demand strongly affect nurses intent to leave. Kar \& Suar [35] studied 862 nurses working in 24 private and public hospitals across six cities in India. The study revealed that nursing specific job demands have impact on nurses' burnout, which affects nurses' job commitment and turnover intentions. Moreover, Joshua-Amdi [60] added another job demands negative consequences that poor work environment such as high workload (quantitative demands), and high level of stress are among the reasons indicated nurses leaving their profession. Finally, ample of research supported the idea that nurses job demands associated strongly and significantly with high level of nurses' job dissatisfaction [7] [15] [16] [17] [61] [62].

In addition, despite job stress was studied in few literatures in Jordan, Jordanian literature never addressed job demands either as independent variable (predictor) or in terms of its relationship with job satisfaction.

\subsection{Job Satisfaction and Job Demands: The Intercorrelation Perspective}

Quinn \& Staines [63] defined job satisfaction as an individual's general feelings about their job. It is an outcome that is concerned with the overall attitude of the employee 
towards their job. While Spector [64] defined job satisfaction as an employee's positive reactions to a job or the extent to which people like their job.

For many years, employee job satisfaction was a concern and it was actively and interestingly studied by researchers. Numerous studies examined causes, predictors and consequences of job satisfaction. Spector, in his literature review categorized the findings into antecedents and possible effects of job satisfaction. Antecedents of job satisfaction were divided into environmental and personal antecedents. In addition, environmental antecedents included job characteristics (e.g., job demands), role variables, organizational constraints, pay, work-family conflict, workload, work schedules, job stress and control. Personal antecedents of job satisfaction include person-job fit, negative affectivity, personality traits, and locus of control. The possible effects or consequences of job satisfaction were also analyzed [64]. Job performance, withdrawal behavior, absenteeism, turnover, and burnout were also noted to be potential effects of job dissatisfaction as were physical health and psychological well-being, counterproductive behavior, and life satisfaction.

The correlation between job satisfaction and outcome variables was widely studied such as job performance, burnout, turnover, and commitment [7] [16] [17]. Furthermore, job satisfaction has been examined as a strong predictor of retention [20] [21] [22], quality of nursing care (e.g., [65]), and quality indicator in health care services [66].

Three recent literature review studies supported the idea of significance of nurses' job satisfaction related to its serious consequences. These consequences affect productivity and performance. Turnover was also widely discussed which in turn affects any health-care delivery system efficiency and effectiveness [7] [16] [17]. The researchers added that nurses' job satisfaction is considered as one of job outcomes (work-family conflict, stress, burnout, and intent to leave), that is affected directly and significantly by high nurses' job demands [7] [16] [17]. Job satisfaction should be a concern because it is the most commonly cited aspect related to nurses' turnover and its high cost [24] [67].

In the same realm, the effect of nurses' job satisfaction in the literature was exhaustive, clearly explained presented by many negative consequences. Lowest level of overall job satisfaction results in higher absenteeism [26] [68]. Yin and Yang's [69] in their meta-analysis also indicated that job satisfaction was one of the organizational factors that were associated with nursing turnover. Moreover a self-administered questionnaire study conducted in Hong Kong by Siu [70] supported the findings that nurses' dissatisfaction over their job is a significant predictor of absenteeism.

Moradi et al. [71] reviewed 36 research studies in which job satisfaction was strongly related and affected by organizational commitment and loyalty. Furthermore, it is also associated with depression, subjective stress, hostility; intensity of stressful events, anxiety and frequency of stressful events. They added, that high level of job satisfaction reflects positive feelings toward the organization, thus having a direct influence on nurse's intent to stay. Consistently, in Japan, a cross-sectional survey of 5956 staff 
nurses on 302 units in 19 acute hospitals, Kanai-Pak et al. [72] studied the association of nurse burnout, job dissatisfaction and quality of care with work environment. They found that $56 \%$ of nurses reported high score on burnout, $60 \%$ were dissatisfied with their jobs and 59\% reported poor quality of care. Burnout and job dissatisfaction were associated with poor retention and poor quality of care. In the same realm, McHugh et al. [23] stated that dissatisfied nurses had high turnover rates and accordingly affecting the quality of care. Finally, many studies supported the relation between dissatisfaction and leaving nursing profession [16] [27] [73].

Although the Jordanian studies have discussed job satisfaction among nurses, the correlates and the values in terms of relationships never addressed job demands amongst. More specifically, job satisfaction was studied in relation to work-related factors in Jordan such as; job satisfaction relation with retention [74], its relation with patient satisfaction and quality of nursing care [65], its relation with job stress and the effect of social support as a moderator [75], its relation to intent to stay [76], its relation to organizational commitment, support, leadership style and educational level [77]. However, the relation between job satisfaction and job demands is not addressed yet in Jordanian studies.

\section{Discussion}

The findings of the studies indicated that work stress is among the universal problems. Nursing profession is a highly demanding stressful and difficult profession, which ranks 12 among the top 20 stressful occupations [6]. Studies added that Job demand is the most effective stressor in nursing and a multi factorial source of stress which is unavoidable factor that lead to many destroying ramifications. These ramifications affect nurses, organizations, and the profession itself which ultimately will be reflected on the quality of care provided to the patient. Studies summarize many negative outcomes of job demand such as staff illness, burnout, turnover, decreased overall quality of care, absenteeism, and low level of job satisfaction. Many studies reported amply the strength of the relationship between job demand and job satisfaction in nursing, and discussed the destroying results of job dissatisfaction like; burnout, turnover, low job performance, commitment, and other serious consequences [7] [16] [17]. So, it is clear that most of negative consequences between job demands and job satisfaction are common and shared.

So, while negative consequences of high job demand and job dissatisfaction in nursing were mentioned clearly in the previous studies and the correlation between them was widely indicated, it is obvious that there is a need for more investigations and more studies that search for factors reducing and alleviating this multifactorial unavoidable stressor (high job demands), and another need to search for moderators that buffer the relationship between job demand and job satisfaction to avoid or reduce its common serious destroying results. This study might get the attention of managers, administrators, educators, and policy makers toward the most significant stressors in nursing profession and the factors that might alleviate and buffer these stressors which ultimately 
could improve the quality of provided care. From the other hand, this study might contribute to the body of knowledge and support studies related to the work environment, job characteristics, and job stress.

\section{Conclusion}

Generally, the findings of the reviewed studies have adequately addressed various forms of occupational and environmental factors that nurses are challenged with. Job demands, job satisfaction are among those factors that have been identified as significant indicators and /or antecedents of quality of nursing care and organizational structure. The literature showed that job demand is multifactorial and has various negative consequences on nurses' ability to function, burnout, absenteeism, presenteeism, poor quality of care, turnovers, and dissatisfaction. In addition, job satisfaction among nurses has a great impact on productivity, organizational commitment, loyalty, and quality of nursing care. Although the connection between the two factors; job demand and job satisfaction, has been examined and well established, other factors have been found to associate and influence the effect of those factors on nurses' performance. Therefore, there is a need to search for such factors that play a significant role in buffering perceived stressors and the correlation between high job demand and job satisfaction. Moreover, there is a need to conduct such studies in Jordan to investigate nursing job demands and it correlates with job satisfaction and the role of factors that alleviate such correlations among nurses.

\section{References}

[1] Butterworth, T., Carson, J., Jeacock, J., White, E. and Clements, A. (1999) Stress, Coping, Burnout and Job Satisfaction in British Nurses: Findings from the Clinical Supervision Evaluation Project. Stress Medicine, 15, 27-33. https://doi.org/10.1002/(SICI)1099-1700(199901)15:1<27::AID-SMI782>3.0.CO;2-U

[2] AbuAlRub, R. (2000) Legal Aspects of Work Related Stress in Nursing: Exploring the Issues. Workplace Health \& Safety, 48, 131-135.

[3] AbuAlRub, R.F. (2004) Job Stress, Job Performance, and Social Support among Hospital Nurses. Journal of Nursing Scholarship, 36, 73-78. https://doi.org/10.1111/j.1547-5069.2004.04016.x

[4] Moustaka, Å. and Constantinidis, T.C. (2010) Sources and Effects of Work-Related Stress in Nursing. Health Science Journal, 4, 210-216.

[5] Hamdan-Mansour, A., El-Gamal, E., Puskar, K. and Marini, A. (2011) Mental Health Nursing in Jordan: An Investigation into Experience, Work Stress, and Organizational Support. International Journal of Mental Health Nursing, 20, 86-94. https://doi.org/10.1111/j.1447-0349.2010.00716.x

[6] International Labor Organization (1999) In Focus Programme on Safety and Health at Work and the Environment. International Labour Organisation Report. www.ilo.org

[7] Cho, S.H., Park, M., Jeon, S.H., Chang, H.E. and Hong, H.J. (2014) Average Hospital Length of Stay, Nurses' Work Demands, and Their Health and Job Outcomes. Journal of Nursing Scholarship, 46, 199-206. https://doi.org/10.1111/jnu.12066

[8] Rowe, J. (2003) The Suffering of the Healer. Nursing Forum, 38, 16-20. 
https://doi.org/10.1111/j.0029-6473.2003.00016.x

[9] Cohen-Katz, J., Wiley, S.D., Capuano, T., Baker, D.M. and Shapiro, S. (2005) The Effects of Mindfulness-Based Stress Reduction on Nurse Stress and Burnout, Part II: A Quantitative and Qualitative Study. Holistic Nursing Practice, 19, 26-35.

https://doi.org/10.1097/00004650-200501000-00008

[10] Rowe, M. and Sherlock, H. (2005) Stress and Verbal Abuse in Nursing: Do Burned out Nurses Eat Their Young? Journal of Nursing Management, 13, 242-248. https://doi.org/10.1111/j.1365-2834.2004.00533.x

[11] Repar, P.A. and Patton, D. (2007) Stress Reduction for Nurses Through Arts-in-Medicine at the University of New Mexico Hospitals. Holistic Nursing Practice, 21, 182-186. https://doi.org/10.1097/01.HNP.0000280929.68259.5c

[12] Stordeur, S. and D'Hoore, W. (2007) Organizational Configuration of Hospitals Succeeding in Attracting and Retaining Nurses. Journal of Advanced Nursing, 57, 45-58. https://doi.org/10.1111/j.1365-2648.2006.04095.x

[13] Rauhala, A. and Fagerstrom, L. (2007) Are Nurses' Assessments of Their Workload Affected by Non-Patient Factors? An Analysis of the RAFAELA System. Journal of Nursing Management, 15, 490-499. https://doi.org/10.1111/j.1365-2834.2007.00645.x

[14] Al-Homayan, A.M., Shamsudin, F.M., Subramaniam, C. and Islam, R. (2013) Impacts of Job Demands on Nurses' Performance Working in Public Hospitals. American Journal of Applied Sciences, 10, 1050-1060. https://doi.org/10.3844/ajassp.2013.1050.1060

[15] Burke, R.J., Moodie, S., Dolan, S.L. and Fiksenbaum, L. (2012) Job Demands, Social Support, Work Satisfaction and Psychological Well-Being among Nurses in Spain. ESADE Business School Research Paper 233.

[16] Hayes, L.J., O’Brien-Pallas, L., Duffield, C., Shamian, J., Buchan, J., Hughes, F., North, N., et al. (2012) Nurse Turnover: A Literature Review-An Update. International Journal of Nursing Studies, 49, 887-905. https://doi.org/10.1016/j.ijnurstu.2011.10.001

[17] Lu, H., Barriball, K.L., Zhang, X. and While, A.E. (2012) Job Satisfaction among Hospital Nurses Revisited: A Systematic Review. International Journal of Nursing Studies, 49, 10171038. https://doi.org/10.1016/j.ijnurstu.2011.11.009

[18] Yildirim, D. and Aycan, Z. (2008) Nurses' Work Demands and Work-Family Conflict: A Questionnaire Survey. International Journal of Nursing Studies, 45, 1366-1378. https://doi.org/10.1016/j.ijnurstu.2007.10.010

[19] Winwood, P.C. and Lushington, K. (2006) Disentangling the Effects of Psychological and Physical Work Demands on Sleep, Recovery and Maladaptive Chronic Stress Outcomes within a Large Sample of Australian Nurses. Journal of Advanced Nursing, 56, 679-689. https://doi.org/10.1111/j.1365-2648.2006.04055.x

[20] Lynn, M.R. and Redman, R.W. (2005) Faces of the Nursing Shortage: Influences on Staff Nurses' Intentions to Leave Their Positions or Nursing. Journal of Nursing Administration, 35, 264-270. https://doi.org/10.1097/00005110-200505000-00010

[21] McCarthy, G., Tyrrell, M.P. and Lehane, E. (2007) Intention to "Leave" or "Stay" in Nursing. Journal of Nursing Management, 15, 248-255.

https://doi.org/10.1111/j.1365-2834.2007.00648.x

[22] Brewer, C.S., Kovner, C.T., Greene, W., Tukov-Shuser, M. and Djukic, M. (2012) Predictors of Actual Turnover in a National Sample of Newly Licensed Registered Nurses Employed in Hospitals. Journal of Advanced Nursing, 68, 521-538. https://doi.org/10.1111/j.1365-2648.2011.05753.x

[23] McHugh, M.D., Kutney-Lee, A., Cimiotti, J.P., Sloane, D.M. and Aiken, L.H. (2011) Nurses' 
Widespread Job Dissatisfaction, Burnout, and Frustration with Health Benefits Signal Problems for Patient Care. Health Affairs, 30, 202-210. https://doi.org/10.1377/hlthaff.2010.0100

[24] Jones, C.B. (2005) The Costs of Nurse Turnover, Part 2: Application of the Nursing Turnover Cost Calculation Methodology. Journal of Nursing Administration, 35, 41-49.

https://doi.org/10.1097/00005110-200501000-00014

[25] George, J.M., Jones, G.R. and Sharbrough, W.C. (2008) Understanding and Managing Organizational Behavior. Addison-Wesley, Reading.

[26] Kreitner, R., Kinicki, A. and Buelens, M. (2007) Organizational Behaviour. McGraw Hill, New York.

[27] Shaver, K.H. and Lacey, L.M. (2003) Job and Career Satisfaction among Staff Nurses: Effects of Job Setting and Environment. Journal of Nursing Administration, 33, 166-172. https://doi.org/10.1097/00005110-200303000-00008

[28] Lambrou, P., Merkouris, A., Middleton, N. and Papastavrou, E. (2014) Nurses Perceptions of Their Professional Practice Environment in Relation to Job Satisfaction: A Review of Quantitative Studies. Health Science Journal, 8, 293-317.

[29] Peeters, M.C., Montgomery, A.J., Bakker, A.B. and Schaufeli, W.B. (2005) Balancing Work and Home: How Job and Home Demands Are Related to Burnout. International Journal of Stress Management, 12, 43-61. https://doi.org/10.1037/1072-5245.12.1.43

[30] McVicar, A. (2003) Workplace Stress in Nursing: A Literature Review. Journal of Advanced Nursing, 44, 633-642. https://doi.org/10.1046/j.0309-2402.2003.02853.x

[31] Beutell, N.J. (2010) Work Schedule, Work Schedule Control and Satisfaction in Relation to Work-Family Conflict, Work-Family Synergy, and Domain Satisfaction. Career Development International, 15, 501-518. https://doi.org/10.1108/13620431011075358

[32] Demerouti, E., Bakker, A.B., Nachreiner, F. and Schaufeli, W.B. (2001) The Job DemandsResources Model of Burnout. Journal of Applied Psychology, 86, 499-512. https://doi.org/10.1037/0021-9010.86.3.499

[33] Lee, J.S. and Akhtar, S. (2011) Effects of the Workplace Social Context and Job Content on Nurse Burnout. Human Resource Management, 50, 227-245. https://doi.org/10.1002/hrm.20421

[34] Demerouti, E., Le Blanc, P.M., Bakker, A.B., Schaufeli, W.B. and Hox, J. (2009) Present but Sick: A Three-Wave Study on Job Demands, Presenteeism and Burnout. Career Development International, 14, 50-68. https://doi.org/10.1108/13620430910933574

[35] Kar, S. and Suar, D. (2014) Role of Burnout in the Relationship between Job Demands and Job Outcomes among Indian Nurses. Vikalpa, 39, 23-37.

[36] Erickson, R. and Grove, W. (2007) Why Emotions Matter: Age, Agitation, and Burnout among Registered Nurses. Online Journal of Issues in Nursing, 13, 1-13.

[37] Gilboa, S., Shirom, A., Fried, Y. and Cooper, C. (2008) A Meta-Analysis of Work Demand Stressors and Job Performance: Examining Main and Moderating Effects. Personnel Psychology, 61, 227-271. https://doi.org/10.1111/j.1744-6570.2008.00113.x

[38] Hamdan-Mansour, A. and Dawani, H. (2008) Social Support and Stress among University Students in Jordan. International Journal of Mental Health and Addiction, 6, 442-450. https://doi.org/10.1007/s11469-007-9112-6

[39] Sohail, M. and Rehman, C.A. (2015) Stress and Health at the Workplace-A Review of the Literature. Journal of Business Studies Quarterly, 6, 94-121.

[40] Xie, Z., Wang, A. and Chen, B. (2011) Nurse Burnout and Its Association with Occupational Stress in a Cross-Sectional Study in Shanghai. Journal of Advanced Nursing, 67, 1537- 
1546. https://doi.org/10.1111/j.1365-2648.2010.05576.x

[41] Greenglass, E.R., Burke, R.J. and Fiksenbaum, L. (2001) Workload and Burnout in Nurses. Journal of Community and Applied Social Psychology, 11, 211-215. https://doi.org/10.1002/casp.614

[42] Ewers, P., Bradshaw, T., Mc Govern, J. and Ewers, B. (2002) Does Training in Psychosocial Interventions Reduce Burnout Rates in Forensic Nurses? Journal of Advanced Nursing, 37, 470-476. https://doi.org/10.1046/j.1365-2648.2002.02115.x

[43] Feldman, P.J., Cohen, S., Hamrick, N. and Lepore, S.J. (2004) Psychological Stress, Appraisal, Emotion and Cardiovascular Response in a Public Speaking Task. Psychology and Health, 19, 353-368. https://doi.org/10.1080/0887044042000193497

[44] Goh, Y.W., Sawang, S. and Oei, T. (2010) The Revised Transactional Model (RTM) of Occupational Stress and Coping: An Improved Process Approach. Australian and New Zealand Journal of Organizational Psychology, 3, 13-20. https://doi.org/10.1375/ajop.3.1.13

[45] Friesen, M.A., White, S.V. and Byers, J.F. (2008) Handoffs: Implications for Nurses. In: Hughes, R.G., Ed., Patient Safety and Quality: An Evidence-Based Handbook for Nurses, Agency for Healthcare Research and Quality, Rockville, 1-48.

[46] Jennings, B. (2008) Work Stress and Burnout among Nurses: Role of the Work Environment and Working Conditions. In: Hughes, R.G., Ed., Patient Safety and Quality: An Evidence-Based Handbook for Nurses, Agency for Healthcare Research and Quality, Rockville, 135-158.

[47] Ohida, T., Kamal, A.M.M., Sone, T., Ishii, T., Uchiyama, M., Minowa, M. and Nozaki, S. (2001) Night-Shift Work Related Problems in Young Female Nurses in Japan. Journal of Occupational Health, 43, 150-156. https://doi.org/10.1539/joh.43.150

[48] Stimpfel, A.W., Sloane, D.M. and Aiken, L.H. (2012) The Longer the Shifts for Hospital Nurses, the Higher the Levels of Burnout and Patient Dissatisfaction. Health Affairs, 31, 2501-2509. https://doi.org/10.1377/hlthaff.2011.1377

[49] Mathew, N.A. (2013) Effect of Stress on Job Satisfaction among Nurses in Central Kerala. Journal of Business and Management, 7, 47-51.

[50] Santos, S.R., Carroll, C.A., Cox, K.S., Teasley, S.L., Simon, S.D., Bainbridge, L., Ott, L., et al. (2003) Baby Boomer Nurses Bearing the Burden of Care. Journal of Nursing Administration, 33, 243-250. https://doi.org/10.1097/00005110-200304000-00010

[51] Al-Maaitah, R., Cameron, S., Horsburgh, M.E. and Armstrong-Stassen, M. (1999) Predictors of Job Satisfaction, Turnover, and Burnout in Female and Male Jordanian Nurses. The Canadian Journal of Nursing Research, 31, 15-30.

[52] Abualrub, R.F. and AL-Zaru, I.M. (2008) Job Stress, Recognition, Job Performance and Intention to Stay at Work among Jordanian Hospital Nurses. Journal of Nursing Management, 16, 227-236. https://doi.org/10.1111/j.1365-2834.2007.00810.x

[53] Lazarus, R.S. and Folkman, S. (1984) Stress, Appraisal, and Coping. Springer, New York.

[54] Doherty, N. and Tyson, S. (1998) Mental Well-Being in the Workplace: A Resource Pack for Management Training and Development. Human Resource Research Centre, Cranfield School of Management, Cranfield University, Cranfield.

[55] Sundin, L., Hochwälder, J. and Lisspers, J. (2011) A Longitudinal Examination of Generic and Occupational Specific Job Demands, and Work-Related Social Support Associated with Burnout among Nurses in Sweden. Work, 38, 389-400.

[56] Chakraborty, R., Chatterjee, A. and Chaudhury, S. (2012) Internal Predictors of Burnout in Psychiatric Nurses: An Indian Study. Industrial Psychiatry Journal, 21, 119-124.

https://doi.org/10.4103/0972-6748.119604 
[57] Demerouti, E., Bakker, A.B., de Jonge, J., Janssen, P.P. and Schaufeli, W.B. (2001) Burnout and Engagement at Work as a Function of Demands and Control. Scandinavian Journal of Work, Environment \& Health, 27, 279-286. https://doi.org/10.5271/sjweh.615

[58] Demerouti, E., Bakker, A.B. and Bulters, A.J. (2004) The Loss Spiral of Work Pressure, Work-Home Interference and Exhaustion: Reciprocal Relations in a Three-Wave Study. Journal of Vocational Behavior, 64, 131-149.

https://doi.org/10.1016/S0001-8791(03)00030-7

[59] Mohamed, N.A. and Mohamed, S.A. (2013) Impact of Job Demand and Control on Nurses Intention to leave Obstetrics and Gynecology Department. Life Science Journal, 10, 223 229.

[60] Joshua-Amadi, M. (2003) Recruitment and Retention in the NHS a Study in Motivation. Nursing Management, 9, 14-19. https://doi.org/10.7748/nm2003.02.9.9.14.c2140

[61] Moyle, P. (2003) The Role of Negative Affectivity in the Stress Process: Tests of Alternative Models. Journal of Organizational Behavior, 16, 647-668.

https://doi.org/10.1002/job.4030160705

[62] McGillis-Hall, L. (2005) Quality Work Environments for Nurse and Patient Safety. Jones \& Bartlett Learning, Burlington.

[63] Quinn, R.P. and Staines, G.L. (1979) The 1977 Quality of Employment Survey. Institute for Social Research, University of Michigan, Ann Arbor.

[64] Spector, P.E. (1997) Job Satisfaction: Application, Assessment, Causes, and Consequences. Vol. 3, Sage Publications, Thousand Oaks.

[65] Mrayyan, M.T. (2006) Jordanian Nurses' Job Satisfaction, Patients' Satisfaction and Quality of Nursing Care. International Nursing Review, 53, 224-230.

https://doi.org/10.1111/j.1466-7657.2006.00439.x

[66] Siqueira, V.T.A. and Kurcgant, P. (2012) Job Satisfaction: A Quality Indicator in Nursing Human Resource Management. Revista da Escola de Enfermagem da USP, 46, 151-157. https://doi.org/10.1590/S0080-62342012000100021

[67] Irvine, D.M. and Evans, M.G. (1995) Job Satisfaction and Turnover among Nurses: Integrating Research Findings across Studies. Nursing Research, 44, 246-253. https://doi.org/10.1097/00006199-199507000-00010

[68] Josias, B.A. (2005) The Relationship between Job Satisfaction and Absenteeism in a Selected Field Services Section within an Electricity Utility in the Western Cape. Doctoral dissertation, University of the Western Cape, Cape Town.

[69] Yin, J.C.T. and Yang, K.P.A. (2002) Nursing Turnover in Taiwan: A Meta-Analysis of Related Factors. International Journal of Nursing Studies, 39, 573-581. https://doi.org/10.1016/S0020-7489(01)00018-9

[70] Siu, O.L. (2002) Predictors of Job Satisfaction and Absenteeism in Two Samples of Hong Kong Nurses. Journal of Advanced Nursing, 40, 218-229.

https://doi.org/10.1046/j.1365-2648.2002.02364.x

[71] Moradi, E., Obaid, A.D., Idrus, D. and Moghadam, F. (2011) Factors Influencing Job Satisfaction among Malaysian Nurses: A Literature Review. 4th Annual International Business Conference, Detroit Metropolitan, 14-16 July 2011, 129-138.

[72] Kanai-Pak, M., Aiken, L.H., Sloane, D.M. and Poghosyan, L. (2008) Poor Work Environments and Nurse Inexperience Are Associated with Burnout, Job Dissatisfaction and Quality Deficits in Japanese Hospitals. Journal of Clinical Nursing, 17, 3324-3329.

https://doi.org/10.1111/j.1365-2702.2008.02639.x 
[73] Eleni, M., Fotini, A., Maria, M., Ioannis, Z.E., Constantina, K. and Theodoros, C.K. (2010) Research in Occupational Stress among Nursing Staff-A Comparative Study in Capital and Regional Hospitals. Hellenic Journal of Nursing Science, 3, 79-84.

[74] Mrayyan, M.T. (2005) Nurse Job Satisfaction and Retention: Comparing Public to Private Hospitals in Jordan. Journal of Nursing Management, 13, 40-50. https://doi.org/10.1111/j.1365-2834.2004.00453.x

[75] Abualrub, R.F., Omari, F.H., AL Rub, A.B.U. and Fawzi, A. (2009) The Moderating Effect of Social Support on the Stress-Satisfaction Relationship among Jordanian Hospital Nurses. Journal of Nursing Management, 17, 870-878. https://doi.org/10.1111/j.1365-2834.2009.01007.x

[76] Mrayyan, M.T. (2007) Jordanian Nurses' Job Satisfaction and Intent to Stay: Comparing Teaching and Non-Teaching Hospitals. Journal of Professional Nursing, 23, 125-136. https://doi.org/10.1016/j.profnurs.2006.12.006

[77] AL-Hussami, M. (2008) A Study of Nurses' Job Satisfaction: The Relationship to Organizational Commitment. Perceived Organizational Support, Transactional, 22, 286-295.

Submit or recommend next manuscript to SCIRP and we will provide best service for you:

Accepting pre-submission inquiries through Email, Facebook, LinkedIn, Twitter, etc. A wide selection of journals (inclusive of 9 subjects, more than 200 journals)

Providing 24-hour high-quality service

User-friendly online submission system

Fair and swift peer-review system

Efficient typesetting and proofreading procedure

Display of the result of downloads and visits, as well as the number of cited articles

Maximum dissemination of your research work

Submit your manuscript at: http://papersubmission.scirp.org/

Or contact health@scirp.org 